\title{
Fish-to-fish transmission of a marine myxosporean
}

\author{
A. Diamant* \\ National Center of Mariculture, Israel Oceanographic and Limnological Research Ltd, PO Box 1212, Eilat 88112, Israel
}

\begin{abstract}
Fish-to-fish transmission of the marine myxosporean Myxidium leei was experimentally demonstrated in sea bream Sparus aurata L. A group of specific-pathogen-free (SPF) fish of $\sim 11 \mathrm{~g}$ each were placed in a wire-mesh cage immersed in a tank holding infected fish. A second group was placed in a tank receiving water discharged from another tank holding diseased fish. After $9 \mathrm{wk}$, the fish were sacrificed and 12 of the $38(31.6 \%)$ test fish from the mesh cage were found to harbor trophozoites, sporoblasts and spores in the posterior gut epithelium, as was readily diagnosed by standard paraffin histology. Of the fish exposed to water discharge, 10 out of $30(33.3 \%)$ showed similar infection. None of the fish examined displayed any proliferative stages of the parasites in the blood, spleen, kidney, liver or gill samples. All of 100 control fish examined remained uninfected. A third group of SPF fish was fed once daily for $7 \mathrm{~d}$ on pieces of freshly dissected $M$. leei-infected gut, after which the fish were maintained on a commercial pellet diet for a further $4 \mathrm{wk}$. Control fish in this experiment were fed only commercial pellets for $5 \mathrm{wk}$. The fish were sacrificed after $5 \mathrm{wk}$, and 4 out of 30 test fish (13\%) were found to be infected. All control fish remained uninfected. Examination of the water sampled from all tanks in which infected fish were held revealed presence of exfoliated gut tissue and mucus casts containing trophozoites, sporoblasts and spores of $M$. leei. Examination of existing potential intermediate hosts yielded definitively negative results for actinosporeans. It is suggested that $M$. leei is transmitted between fish by ingestion of excretions from infected fish. The results reveal that sharing facilities with diseased fish as well as exposure to contaminated water is a route for parasite transmission. In general contrast to the freshwater myxosporeans studied to date, the present study of a marine species provides evidence that direct transmission can take place without need for actinosporean development in an alternate (oligochaete) host. It is suggested that this may be a model for the development of other marine myxosporeans as well.
\end{abstract}

KEY WORDS: Direct transmission - Myxidium leei Sea bream

\section{INTRODUCTION}

Although the majority of Myxosporea identified to date are marine species, the most intensive work carried out to date on this important group of parasites has dealt with freshwater species that infect freshwater, anadromous or catadromous fish hosts (e.g. carp, trout, salmon, eel, etc.). Based on 12 to 15, all of them freshwater, of the approximately 1250 recognized myxosporean species, the transmission route via actinosporean stage in oligochaetes as proposed by Wolf \& Markiw (1984) is now accepted by many as universal for the group (Lom \& Dykova 1995). According to this model, development of the Myxosporea includes an obligatory alternation of myxosporean-fish and actino-

·E-mail: diamant@agri.huji.ac.il sporean-oligochaete development for completion of the parasitic life cycle. Lom (1989) reported 37 known actinosporeans as opposed to 1000 myxosporeans. He pointed out that if each myxosporean had a matching actinosporean, the relatively few known actinosporeans were evidently greatly outnumbered, particularly in the marine environment (Lom 1987). Indeed, the actinosporean-myxosporean transformation route has yet to be demonstrated in a marine myxosporean. Recently, Kent et al. (1994) suggested that some marine myxosporean species may utilize invertebrates other than oligochaetes as alternate hosts, while others may have evolved (or retained) the ability to infect fish without need of any alternate actinosporean development whatsoever.

Up to the significant discovery of Wolf \& Markiw (1984), it was generally accepted that myxosporean 
spores must age or 'ripen' outside the fish host for an extended period before they become infective to fish (Lom 1989). It was assumed for many years that 'fish become infected with Myxosporidia by swallowing their spores; no intermediate host is included in the cycle' (Polyanski 1961). This conformed with the classic hypothesis that after ingestion of the myxosporean spore, the sporoplasm escaped from the shell in the digestive tract of the fish as a small amoebula, crossed the intestinal wall and migrated via the bloodstream or lymphatic system to the target organ (Noble 1944). Indeed, successful direct transmission via spores was reported in a few cases of Myxobolus spp. and Sphaerospora renicola (Hoffman \& Putz 1969, Prihoda 1983, Odening et al. 1989). However, this hypothetical course of events remained unsettled, since most direct fish-to-fish infection trials using spores were unsuccessful (all in freshwater species, e.g. Schafer 1968 , Fryer \& Sanders 1970, Wyatt 1978, El-Matbouli \& Hoffmann 1989, Grossheider \& Korting 1992, Kent et al. 1994).

Myxidium leei is a marine myxosporean that infects sea bream Sparus aurata and at least 3 other cultured sparids, Diplodus puntazzo, Pagrus major and Pagrus pagrus (Diamant 1992, 1995, Diamant et al. 1994, Sakiti et al. 1995, Le Breton \& Marques 1995, Tarer et al. 1996). An accidental introduction into the Gulf of Eilat via imported fish culture stocks, this histozoic pathogen of Mediterranean origin has become established in the tropical marine region of the northern Red Sea (Diamant 1995).

In the last year, sea bream brood stock in a fish hatchery in southern Israel exhibited persistent, continuous low grade mortalities. Examination of these fish demonstrated chronic Myxidium leei gut infections as previously described by several authors (Diamant 1992, Diamant et al. 1994, Le Breton \& Marques 1994).

This report presents the details of experiments carried out with Myxidium leei in sea bream and designed to determine the mode of transmission of this parasite.

\section{MATERLALS AND METHODS}

All experiments were carried out in a flow-through sand-filtered seawater system. In June 1996, 24 Myxidium leei-infected fish (600 to $700 \mathrm{~g}$ ) brood stock were obtained from a commercial hatchery. All were examined for $M$. leei spores in mucosa scrapings sampled through the vent and verified to be infected. Fish were acclimated for $6 \mathrm{wk}$ in 2 groups of 12 in $600 \mathrm{l}$ tanks marked 'Tank A' and 'Tank B'. These fish were used as $M$. leei donor fish.
For experimental exposure, several hundred specificpathogen-free (SPF) juvenile sea-bream from laboratory-bred stock were obtained from the National Center for Mariculture (NCM) Genetics Department. Mean weight was $11.3 \mathrm{~g}$ (7.1 to $20.0 \mathrm{~g} ; \mathrm{n}=20$ ). All test fish and controls were maintained on a commercial dry pellet diet prior to the experiments

Three types of procedure were used to investigate the transmission of Myxidium leei to test fish: (1) exposing test fish in a wire mesh cage immersed in a tank holding infected fish (cohabitation), (2) exposing test fish to water discharged from a tank holding infected fish (effluent), and (3) feeding test fish with pieces of infected gut tissue containing $M$. leei trophozoites, sporoblasts and spores.

Cohabitation. A group of 50 test fish was placed in a $40 \times 40 \times 80 \mathrm{~cm}$ protective $1 \mathrm{~cm}$ wire mesh cage immersed in Tank $A$. This allowed cohabitation between the 2 stocks, yet kept the much larger infected (donor) fish from physically harming the smaller test fish.

Effluent. A group of 50 test fish was placed in an $80 \mathrm{l}$ tank next to Tank B. The $80 \mathrm{l}$ tank received its water supply from Tank B through a pipe, so that the test fish were continually exposed to discharged water from the tank of infected fish.

Controls. There were 2 control groups, C and D, each consisting of 2 tanks of $50 \mathrm{l}$ with 30 test fish. Control ' $C$ ' was supplied with sand-filtered sea water, and control ' $\mathrm{D}$ ' with unfiltered water pumped directly from the sea. A total of 50 fish were sampled from each of the control groups.

All treatments and controls (A, B, C and D) were sampled in Weeks 2, 4, 6, 7, 8 and 9. Each sampled fish was anesthetized, weighed, and sacrificed, and a blood smear was taken. The viscera were dissected and a fresh mucosa scraping of the posterior gut examined. The alimentary tract, liver, spleen, kidney and gills were fixed and processed for paraffin histology. Fish that died during the experiment, condition permitting, were necropsied and examined for Myxidium lee presence in the gut. The experiment was terminated at the end of $9 \mathrm{wk}$, when all remaining fish were sacrificed. Altogether, 168 test and control fish were examined.

Samples of fouling organisms were scraped off the sides of Tanks A and B for identification throughout the $9 \mathrm{wk}$ period. Likewise, the water effluent from Tank B was examined. Filtrates through a $200 \mu \mathrm{m}$ plankton mesh were examined periodically during the experiment.

Feeding. A group of 63 test fish was divided into 2 groups and placed in 2 clean $50 \mathrm{l}$ tanks. The 30 fish in the treatment tank were fed daily over the first week with bits of freshly dissected gut tissue from infected 
fish. For the next $4 \mathrm{wk}$, they were maintained on a commercial pellet diet. The control group of 33 fish was fed a commercial pellet diet throughout the entire 5 wk. Both tanks were cleaned and siphoned daily and kept free of fouling organisms. The fish of both groups were sacrificed simultaneously at the end of $5 \mathrm{wk}$ and processed for paraffin histology.

Tissue processing. Small pieces of tissue were fixed in buffered neutral formalin and processed using standard procedures for paraffin embedding and sectioning (Sheehan \& Hrapchak 1980). Sections ( $7 \mu \mathrm{m})$ were stained with hematoxylin and eosin, PAS, Gram stain or Giemsa. Test fish were considered positive (infected) only if mature spores could be demonstrated in a scraping of the posterior gut mucosa upon sacrifice and if clear histological evidence of parasite infection was subsequently demonstrated.

\section{RESULTS}

\section{Cohabitation}

Results of the $9 \mathrm{wk}$ cohabitation experiment are summarized in Table 1. Low grade mortalities of fish in the wire mesh cage began in Week 2 and persisted throughout the experiment. A total of 38 test fish was examined during the $9 \mathrm{wk}$ period. Infected fish were first detected in Week 7, when 4 of 8 fish examined were found positive for Myxidium leei. Histology revealed 12 fish (31.6\%) with PAS-positive trophozoites and sporoblasts developing in the posterior intestine. The blood smears of all examined fish, as
Table 1. Results of experiments testing for transmission of Myxidium leei to specific-pathogen-free (SPF) Sparus aurata by close association with infected $S$. aurata. Numbers indicate infected fish recorded per no. examined (in parentheses) in weekly samples. Pindicates total (cumulative) prevalence (\%) of infection per treatment

\begin{tabular}{|c|c|c|c|c|}
\hline \multirow[t]{2}{*}{ Week } & \multirow{2}{*}{$\begin{array}{l}\text { Cohabitation } \\
\text { Tank A }\end{array}$} & \multirow{2}{*}{$\begin{array}{l}\text { Effluent } \\
\text { Tank B }\end{array}$} & \multicolumn{2}{|c|}{ Controls } \\
\hline & & & Tank C & Tank D \\
\hline 2 & $0(3)$ & $1(3)$ & $0(3)$ & $0(3)$ \\
\hline 4 & $0(5)$ & $1(5)$ & $0(5)$ & $0(5)$ \\
\hline 6 & $0(3)$ & $3(4)$ & $0(5)$ & $0(5)$ \\
\hline 7 & $4(8)$ & $2(7)$ & $0(10)$ & $0(10)$ \\
\hline 8 & $5(10)$ & $2(5)$ & $0(10)$ & $0(10)$ \\
\hline 9 & $3(9)$ & $1(6)$ & $0(17)$ & $0(17)$ \\
\hline Total & $12(38)$ & $10(30)$ & $0(50)$ & $0(50)$ \\
\hline $\mathrm{P}(\%)$ & 31.6 & 33.3 & 0 & 0 \\
\hline
\end{tabular}

well as the histological sections of their sampled organs, revealed no developmental stages of myxosporea or any distinct pathological features attributable to parasite infection.

\section{Effluent}

Results of the effluent experiment are summarized in Table 1. Low grade mortalities began in Week 2 and persisted throughout the experiment. A total of 30 test fish was examined during the $9 \mathrm{wk}$ period. The first infected test fish were recorded in Week 2 , when 1 of 3 examined fish was infected. In histological sections, the posterior intestine of 10 of the fish exhibited
Fig. 1. Myxidium leei. Trophozoites and sporoblasts developing in the intestinal mucosa of experimentally infected sea bream Sparus aurata 7 wk after exposure to contaminated water discharge from tank with infected fish. H\&E (scale bar $=10 \mu \mathrm{m}$ )

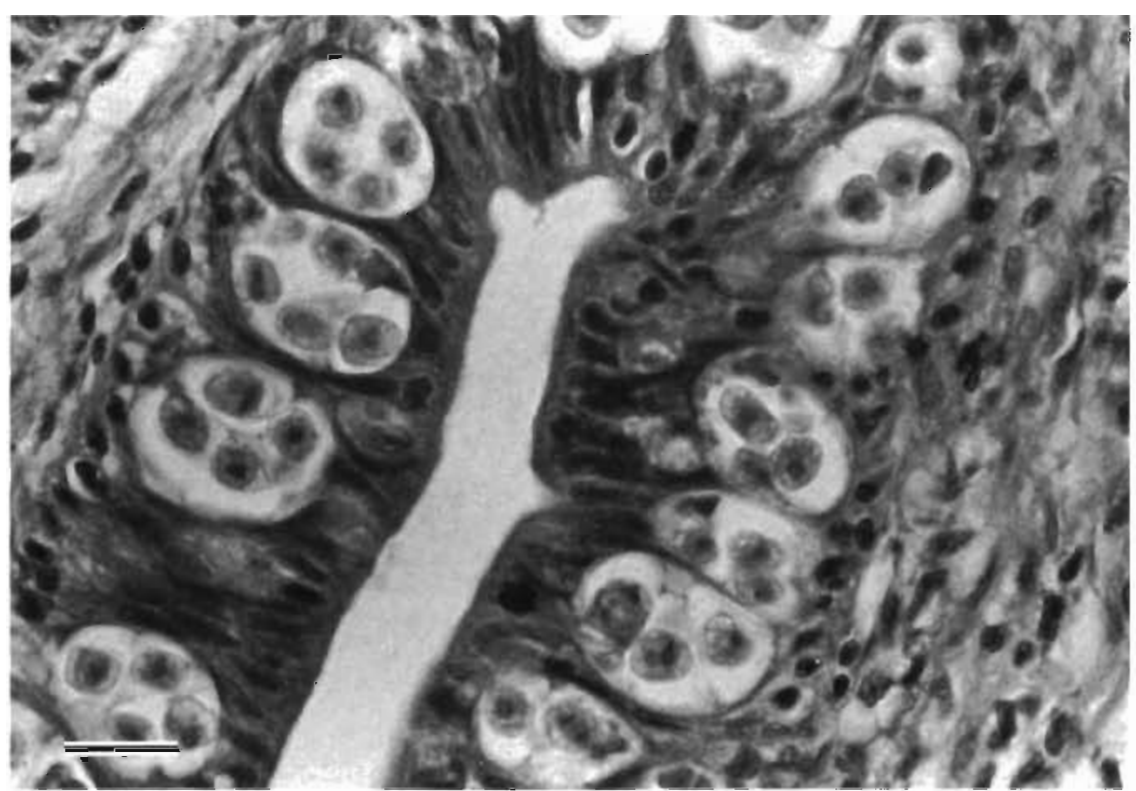


Table 2. Results of experiment testing for transmission of Myxidium leei to Sparus aurata by feeding with freshly dissected gut tissue of infected $S$. aurata. $\mathrm{n}=$ no. of fish, $p=$ cumulative prevalence $(\%)$ of infection

\begin{tabular}{|lcc|}
\hline & Feeding & Control \\
\hline $\mathrm{n}$ & 30 & 33 \\
Infected & 4 & 0 \\
$\mathrm{P}(\%)$ & 13.3 & 0 \\
\hline
\end{tabular}

numerous trophozoites and sporoblasts developing in the mucosa (Fig. 1). The blood smears and histological sections of all other sampled organs revealed no distinct pathological features.

\section{Controls}

Fish in both control treatments $C$ (unfiltered seawater) and D (sand-filtered sea water) suffered no mortalities during the experiment. A total of 50 fish was examined from each control. None of the fish had any histological evidence of Myxidium leei infection (Table 1).

\section{Examination of filtrate}

Examination of the effluent water filtrate in Tank B revealed a variety of minute organisms, including nematodes, copepods, various protozoa, macroalgal debris, fungi and bacteria. Casts of fish fecal and mucous matter and gut mucosa tissue fragments containing myriads of live Myxidium leei trophozoites, sporoblasts and spores were also found in the filtrate (Figs, 2, $3 \& 4$ ).

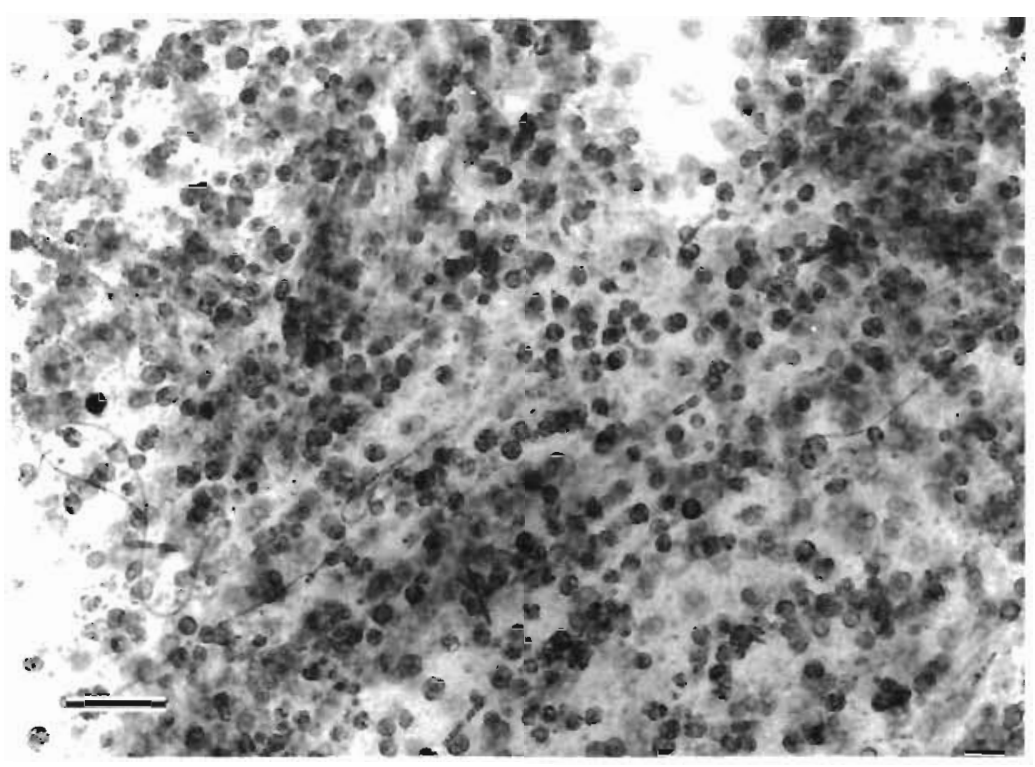

Fig. 2. Myxidium leei. Numerous trophozoites, sporoblasts and spores in mucus cast excretion recovered from water discharged from tank holding infected fish. Fresh mount (scale bar $=125 \mu \mathrm{m}$ )

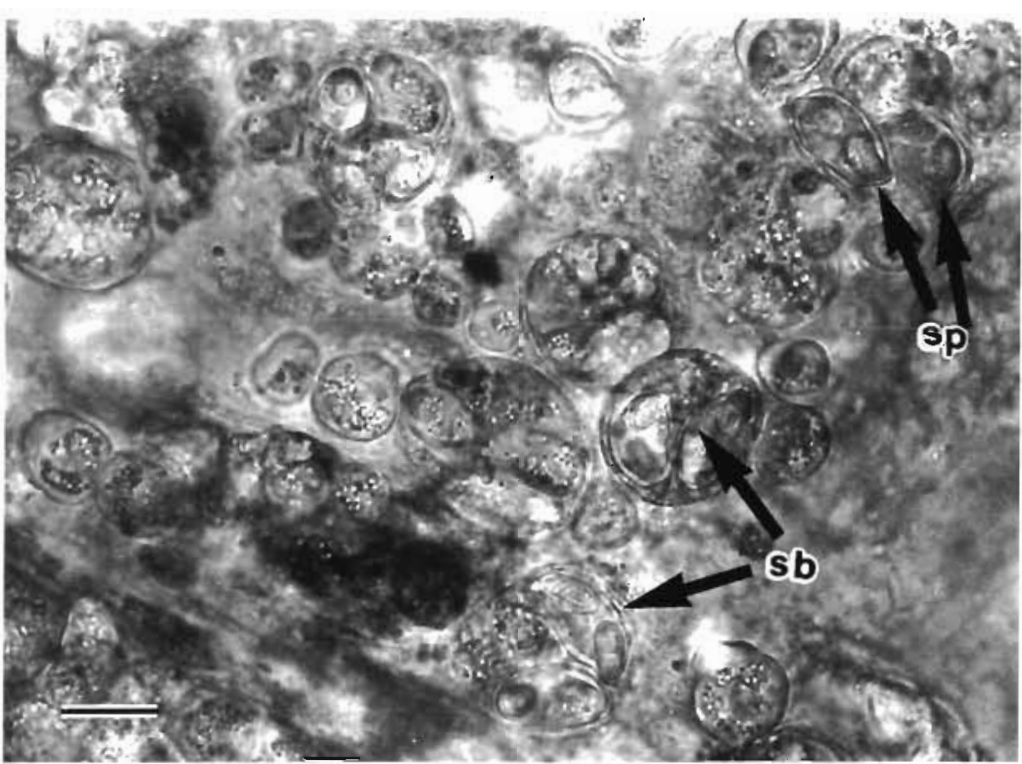

Fig. 3. Myxidium leei. High-power magnufication of material in Fig. 2. Small round cells are young trophozoites; sb: sporoblasts; sp: spores. Fresh mount (scale bar $=10 \mu \mathrm{m}$ )

\section{Examination of fouling organisms for actinosporeans}

Samples of fouling organisms scraped off the sides of Tanks A and B yielded copepods, polychaetes, oligochaetes, nematodes, coelenterates, protozoa and filamentous algae. Actinosporeans were searched for repeatedly in water filtrates and in squash preparations of the different invertebrates. However, despite considerable effort, not a single actinosporean was found.

\section{Feeding}

Results of feeding trials are presented in Table 2. Four $(13.3 \%)$ of the 30 test fish fed with infected gut tissue displayed hindgut infections with Myxidium leei trophozoites, sporoblasts and spores (Figs. 5 $\& 6)$. All 33 fish of the control group remained uninfected. 


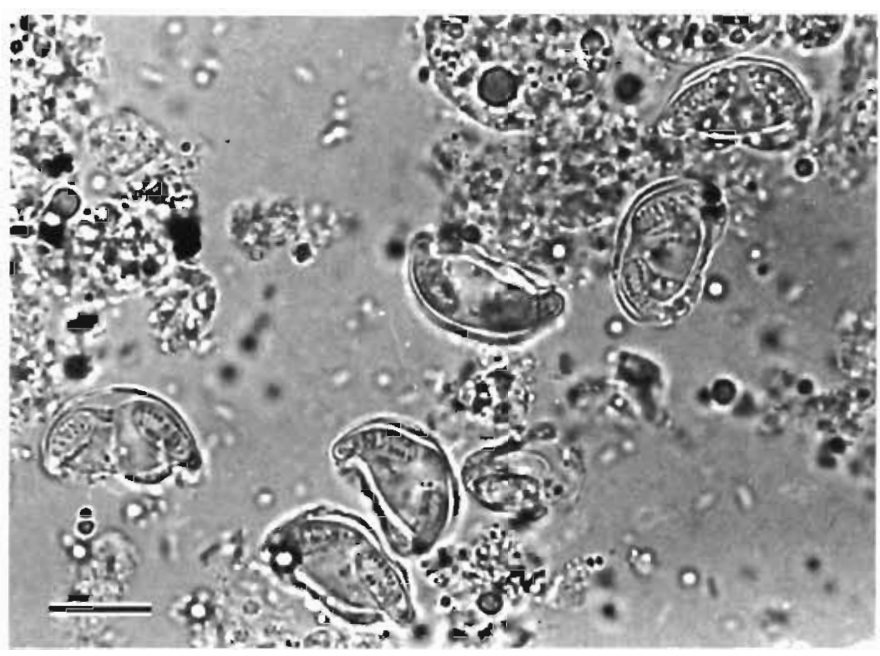

Fig. 4. Myxidium leei. Mature spores in mucus cast recovered from water discharged from tank holding infected fish. Fresh mount (scale bar $=10 \mu \mathrm{m}$ )

\section{DISCUSSION}

The results of the present study indicate that Myxidium leei is transmittable between fish via ingestion of infected fish tissue and through waterborne contamination. Although only about $30 \%$ of the test fish in the exposure treatments became infected, these fish displayed heavy infection with trophozoites, sporoblasts and spores in the gut tissue. This may suggest that, following initial invasion of the host, the parasite under-

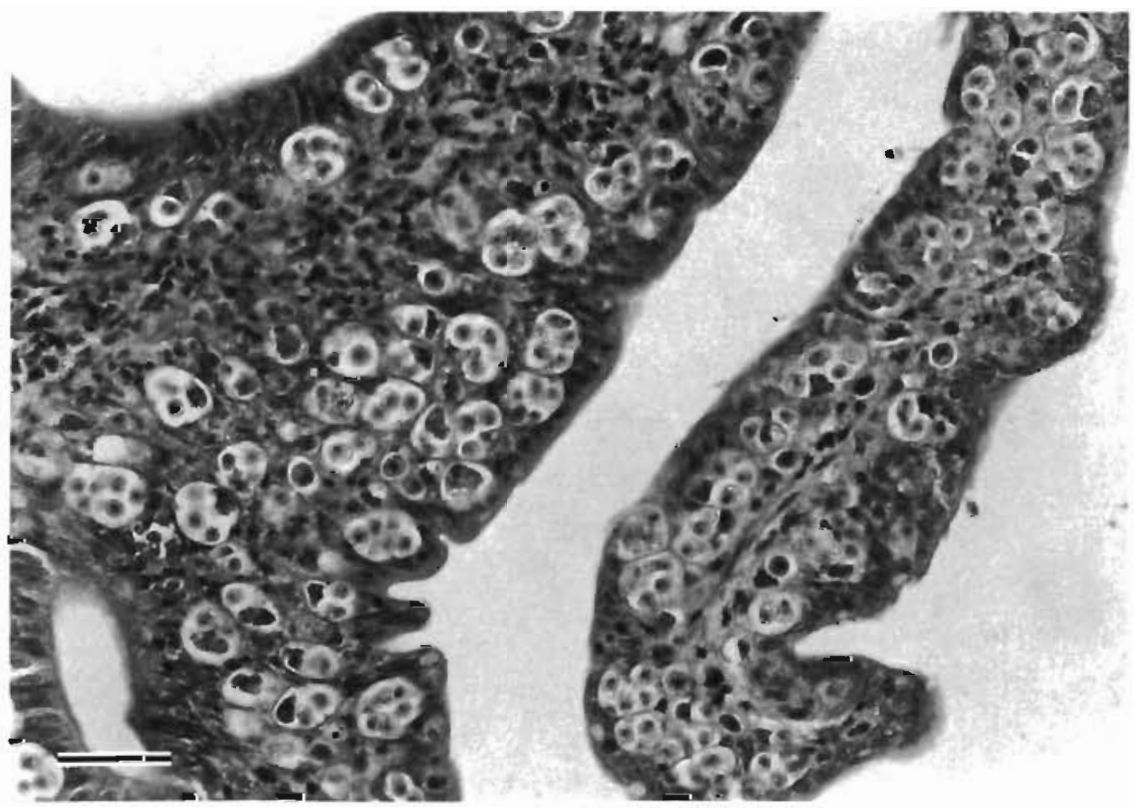

Fig. 5. Myxidium leei. Trophozoites, sporoblasts and spores developing in the gut mucosa of experimentally infected sea bream Sparus aurata 5 wk after feeding on contaminated fish tissue. H\&E (scale bar $=35 \mu \mathrm{m}$ )

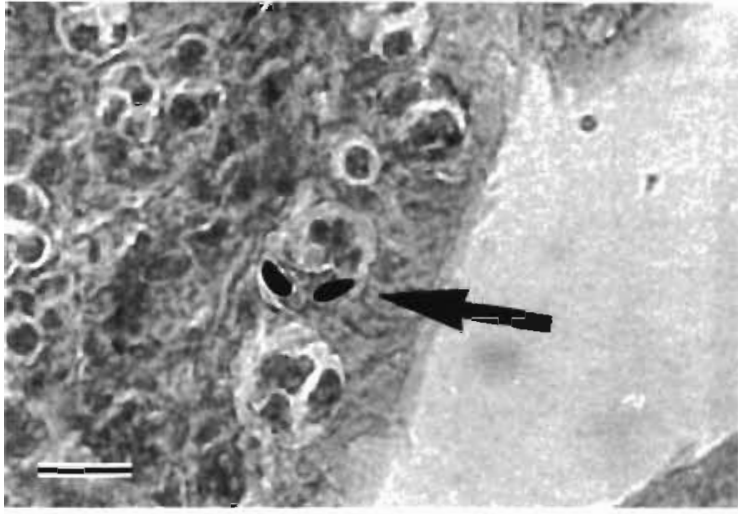

Fig. 6. Myxidium leei. Experimentally infected sea bream, portion of specimen shown in Fig. 5, showing intensely stained polar capsules of spore positioned in the gut mucosa. Gram stain (scale bar $=15 \mu \mathrm{m}$ )

went a phase of presporogonic proliferation, as described for the Myxosporea by Lom \& Dykova (1995), whereby the infection spreads throughout the target tissue and yields large numbers of plasmodia as a stage preceding sporogony. This possibility would be supported by the observations of Tarer et al. (1996), who previously proposed that each developing $M$. leei pansporoblast forms an extra 2 bicellular entities which may promote rapid re-infection of the same host. The rapid proliferation may theoretically also be a result of autoinfection (i.e. parasite sporogenesis followed by spore maturation and hatching, all in the same host; Lom \& Dykova 1995), since the results of experiment $\mathrm{C}$ (feeding with infected gut) suggest that a period of spore 'ripening' outside the host may not be necessary for successful infection in this species. It would seem unlikely that the observed infection pattern could result from massive ingestion of spores by the test fish, since in such a case we could expect a higher prevalence than the 10 to $33 \%$ observed in the experiments

According to present taxonomic criteria which are based on spore morphology, Myxidium leei shares spore characteristics with both Myxidium and Zschokkella (see Diamant et al. 1994). Actinosporeans have been shown to participate in the life cycles of both genera. The genus Aurantiactinomyxon is involved in the 
developmental cycle of Myxidium giardi (Benajiba \& Marques 1993), and comparable development has been demonstrated for the actinosporean Siedleckiella silesica and Zschokkella nova by Uspenskaya (1995). Fish-myxosporean and oligochaete-actinosporean alternate development have also been demonstrated in additional freshwater fish hosts for Zschokkella and Myxidium by Yokoyama et al. (1991) and Benajiba \& Marques (1993). However, transmission of the present species seems to vary from the above cases dealing with these 2 genera.

Although actinosporeans are found in marine invertebrates (Shul'man 1988), and it is reasonable to assume that the actinosporean-myxosporean transformation does occur in the sea, not a single marine myxosporean life cycle has yet been shown to include an actinosporean phase in its development. Only 2 species, both of the genus Sphaeractinomyxon, have been recorded from marine oligochaete worms, but neither has been associated with a corresponding fish myxosporean (Hallett et al. 1995).

The experiment in which test fish were fed freshly dissected Myxidium leei-infected gut tissue was kept scrupulously clean of fouling organisms for the entire duration of the $5 \mathrm{wk}$. In the exposure experiments (Tanks A and B), oligochaetes as well as other invertebrates did occur amongst the fouling organisms, but it seems unlikely that these played any role in the transmission, since no actinosporeans were found in repeated examinations of water or in squash preparations of the various invertebrates. Moreover, not a single one of the 133 control fish in the different control groups became infected.

Oligochaete worms are considered to have evolved in freshwater and subsequently spread to marine habitats (Giere \& Pfannkuche 1982). On the other hand, the class Myxosporea has been considered to be primarily a marine group which later spread to freshwater habitats (Lom \& Noble 1984, Shul'man 1988). If we accept these assumptions, it would seem unlikely that oligochaetes should play a decisive role in the transmission of the numerous forms of marine Myxosporea. According to this hypothesis, it may be predicted that oligochaetes will ultimately be found to play a reduced, yet important role in the transmission of myxosporea in the freshwater-marine interface of estuarine habitats. In the sea, the myxosporeans may eventually be found to utilize other annelids, but so far this possibility has not been confirmed, thus favoring the likelihood of direct transmission.

Fish-to-fish transmission in marine myxosporeans may be inferred from parasitological studies of migratory marine fish. Successful transportation of parasites during fish migration is more likely to occur in monoxenic species or in heteroxenic species when the inter- mediate host has migrated as well (or in cases of low parasite-host specificity) (Petrushevski 1961, Paperna 1972, Bauer 1991). Study of the Red-Med (Suez Canal) fish immigrants Siganus rivulatus and $S$. luridus (Siganidae) has shown that parasites requiring one or more intermediate hosts have not followed the fish into the Mediterranean; only monogenea, endoparasitic and ectoparasitic protozoa have been recovered from the immigrant fish (Diamant 1989). Two myxosporean species, Zschokkella icterica and Ceratomyxa sp., are the only presumably heteroxenic parasitic species which have persisted. Their endurance on the immigrant Siganus population may alternatively be interpreted as a result of the ability to be directly transmitted from fish to fish.

Direct transmission of Myxidium leei explains the rapid spreading of myxidiosis to an increasing number of Mediterranean fish farms (Tarer et al. 1996). Infections of $M$. leei are evidently transmitted via waterborne spore-laden gut mucosa fragments and mucous casts excreted by the diseased fish. At the same time, natural transmission can presumably take place through necrophagy, which is common in fish, particularly fish in captivity. Whether the infection occurs through transfer of vegetative stages which are capable of surviving the host's digestive tract [as the results of previous studies, e.g. Odening et al. (1989), may suggest], or whether it occurs through ingestion of spores without any intermediate host, the capacity of $M$. leei to be transmitted horizontally between fish by fish feeding on infected tissue, by cohabitation or through waterborne contamination is of great relevance to sparid mariculture management in regions where the disease is enzootic.

Acknowledgements. The invaluable support of N. Wajsbrot and Dr S. Gorshkov during this study is gratefully acknowledged, as is the technical assistance of S. Turkia and B. Colorni. Special thanks are due to Prof. I. Paperna, Dr A. Colorni and an anonymous reviewer for helpful remarks on the manuscript. This study was carried out at the Green-Keiser Fish Health Center, National Center of Mariculture and supported by the Israel Ministry of National Infrastructures.

\section{LITERATURE CITED}

Bauer ON (1991) Spread of parasites and diseases of aquatic organisms by acclimatization: a short review. J Fish Biol 39:679-686

Benajiba MH, Marques A (1993) The alternation of Actinomyxidian and Myxosporidian sporal forms in the development of Myxidium giardi (parasite of Anguilla anguilla) through oligochaetes. Bull Eur Assoc Fish Pathol 13: $100-103$

Diamant A (1989) Lessepsian migrants as hosts: a parasitological assessment of rabbitfish Siganus luridus and Siganus rivulatus (Siganidae) in their original and new zoogeo- 
graphical regions. In: Spanier E, Steinberger Y, Luria M (eds) Environmental quality and ecosystem stability, Vol IV-B, Environmental quality. ISEEQS Pub Jerusalem, p $187-194$

Diamant A (1992) A new pathogenic histozoic Myxidium (Myxosporea) in cultured gilt-head sea bream Sparus aurata L. Bull Eur Assoc Fish Pathol 12:64-66

Diamant A (1995) Myxidium leei (Myxosporea) infections in sharpsnout sea bream Diplodus puntazzo (Cetti) and common sea bream Pagrus pagrus (L.) (Sparidae). 4th Int Symp Fish Parasitology, Munich, Germany, Oct. 3-7, 1995. Program and book of abstracts. Institute of Zoology, Fish Biology and Fish Diseases, University of Munich, p 8

Diamant A, Lom J, Dyková I (1994) Myxidium leei n. sp., a pathogenic myxosporean of cultured sea bream Sparus aurata. Dis Aquat Org 20:137-141

El-Matbouli M. Hoffmann RW (1989) Experimental transmission of two Myxobolus spp. developing bisporogony via tubificid worms. Parasitol Res 75:461-464

Fryer JL, Sanders JE (1970) Investigation of Ceratomyxa shasta, a protozoan parasite of salmonid fish. J Parasitol $56: 759$

Giere O, Pfannkuche O (1982) Biology and ecology of marine oligochaeta, a review. Oceanogr Mar Biol Annu Rev 20. $173-308$

Grossheider G, Körting W (1992) First evidence that Hoferellus cyprini (Doflein, 1898) is transmitted by Nais sp. Bull Eur Assoc Fish Pathol 12:17-20

Hallet SH, Erseus C, Lester RJG (1995) An actinosporean from an Australian marine oligochaete. Bull Eur Assoc Fish Pathol 15:168-171

Hoffman GL, Putz RE (1969) Host susceptibility and the effect of ageing, freezing, heat and chemicals on spores of Myxobolus cerebralis. Prog Fish-Cult 31:35-37

Kent ML, Margolis L, Corliss JO (1994) The demise of a class of protists: taxonomic and nomenclatural revisions proposed for the protist phylum Myxozoa Grasse, 1970. Can J Zool 72:932-937

Le Breton A, Marques A (1995) Occurrence of a histozoic Myxidium infection in two marine cultured species: Puntazzo puntazzo C. and Pagrus major. Bull Eur Assoc Fish Pathol 15:210-212

Lom J (1987) Myxosporea: a new look at long known parasites of fish. Parasitol Today 3:327-332

Lom J (1989) Phylum Myxozoa. In: Margulis L, Corliss JO, Melkonian M. Chapman DJ (eds) Handbook of protoctista. Jones and Bartlett Publ, Boston, p 36-52

Lom J, Dyková I (1995) Myxosporea (Phylum Myxozoa). In: Woo PTK (ed) Fish diseases and disorders. CAB International, Wallingford, p 97-148

Lom J, Noble ER (1984) Revised classification of the class Myxosporea Butschli, 1881. Folia Parasitol (Praha) 31:193-205

Responsible Subject Editor: Wolfgang Körting, Hannover, Germany
Noble ER (1944) Life cycles in the Myxosporidia. Q Rev Biol 19:213-235

Odening K, Walter G, Bockhardt I (1989) Zum Infektionsgeschehen bei Sphaerospora renicola (Myxosporidia) Angew Parasitol 30:131-140

Paperna I (1972) Parasitological implications of fish migration through interoceanic canals. 17th Congr Intl Zool (Monte Carlo, Sept 1972). Thème No 3: Les conséquences biologiques des canaux inter-océans, p 1-9

Petrushevski GK (1961) Changes in the parasite fauna of acclimatised fishes. In: Dogiel VA, Petrushevski $\mathrm{KG}$, Polyanski YI (eds) Parasitology of fishes. Oliver \& Boyd, Edinburgh, p 255-264

Polyanski YI (1961) Ecology of parasites of manine fishes. In: Dogiel VA, Petrushevski KG, Polyanski YI (eds) Parasitology of fishes. Oliver \& Boyd, Edinburgh, p 48-83

Prihodà $J$ (1983) Experimental infection of rainbow trout fry with Myxosoma cerebralis Hoffer, 1903. In: Parasites and parasitic diseases of fish. Proc 1st Int Symp Ichthyoparasitology, 8-13 August 1983. Institute of Parasitology, Czechoslovak Academy of Sciences, Ceské Budějovice, p 98 (Abstract)

Sakiti N, Kabre DG, Tarer V, Marques A. (1995) First description in Myxidium leei of a cellular structure intervening in the pathogenesis of Sparus aurata in aquaculture. 2nd Eur Congr Protistology, July 21-26, Clermont-Ferrand, France. Eur J Protistol 31:459

Schafer WE (1968) Studies on the epizootiology of the myxosporidian Ceratomyxa shasta Noble. Calif Fish Game 54: $90-99$

Sheehan DC, Hrapchak BB (1980) Theory and practice of histotechnology, 2nd edn. CV Mosby Co, St. Louis

Shul'man SS (1988) Myxosporidia of the USSR (Mikrosporidii Fauny SSSR, Nauka Pub. Moscow-Leningrad). Translated from Russian, Amerind Publ Co, New Delhi

Tarer V, Sakiti ND, Le Breton A, Marques A (1996) Myxidium leei myxosporidie pathogène chez les sparides en aquaculture en Méditerranée. Ichthyophysiol Acta 19:127-139

Uspenskaya AV (1995) Alternation of actinosporean and myxosporean phases in the life cycle of Zschokkella nova (Myxozoa) J Eukaryot Microbiol 42(6):665-668

Wolf K, Markiw ME (1984) Biology contravenes taxonomy in the Myxozoa: new discoveries show alternation of invertebrate and vertebrate hosts. Science 225:1449-1452

Wyatt EJ (1978) Studies on the epizootiology of Myxobolus insidiosus Wyatt and Pratt, 1963 (Protozoa: Myxosporidia). J Fish Dis 1:233-240

Yokoyama H, Ogawa K, Wakabayashi H (1991) A new collection method of actinosporeans - a probable infective stage of myxosporeans to fishes-from tubificids and experimental infection of goldfish with the actinosporean, Raabeia sp. Gyobyo Kenkyu 26:133-138

Manuscript received: April 11, 1997

Revised version accepted: May 28, 1997 